\title{
PENGARUH PENGGUNAAN WHATSSAPP DAN METODE PEMBELAJARAN PROJECT BASED LEARNING TERHADAP PEMBELAJARAN BAHASA ARAB
}

\author{
Isti Azhura Nurazmi \\ Universitas Pendidikan Indonesia, Bandung, Indonesia \\ istiazhura@gmail.com
}

\begin{abstract}
ABSTRAK
Tujuan penelitian ini adalah untuk menggambarkan tentang penerapan penggunaan aplikasi daring whatssapp dan metode pembelajaran project based learning khususnya pada program pendidikan jarak jauh di masa pandemi covid-19 ini di Mts Al-Wathoniyah Al-Hamidiyah. Kombinasi penggunaan whatssapp dan metode pembelajaran project based learning lebih efektif dalam meningkatkan hasil belajar siswa. Dalam melakukan penelitian, peneliti menggunakan pendekatan kualitatif dengan metode case study. Pengumpulan data menggunakan teknik wawancara, observasi, dan studi dokumentasi. Di dalam penelitian ini, peneliti mengambil 4 aspek pembelajaran untuk dijadikan fokus penelitian, yaitu: perencanaan, pelaksanaan, evaluasi, dan faktor kekurangan dan kelebihan. Berdasarkan hasil penelitian yang telah dilakukan menunjukkan bahwa terdapat kegiatan perencanaan pembelajaran selama dilaksanakannya pendidikan jarak jauh.
\end{abstract}

Kata Kunci: Aplikasi Daring Whatssapp, Project Based Learning, Pendidikan Jarak Jauh

\section{ABSTRACT}

This study aims to describe the use of WhatsApp and project-based learning method, especially in the program distance education during the COVID-19 pandemic at MTs Al- Wathoniyah Al-Hamidiyah. The combination of using these methods is effective in improving students learning outcomes. The qualitative approach with the case study method is used here. The researcher takes four aspects of learning to focus on the study: planning, implementation, evaluation, and lack and strength factors. The results show that there are activities for planning the learning of distance education.

Keywords: WhatsApp, Project Based Learning, Distance Education 


\section{PENDAHULUAN}

Menurut (Al-Jaburi, 2013, p. 143)pendidikan disebut proses yang menyebabkan orang lain menjadi belajar, dan itu adalah proses yang berkembang di dalam sekolah atau non sekolah pada suatu waktu atau waktu yang lain dan dilakukan oleh guru atau orang lain dengan maksud membantu individu untuk belajar dan memperoleh pengalaman.

Menurut Duffy dan Rochler (Gulo, 2002) pembelajaran adalah suatu usaha yang sengaja melibatkan dan menggunakan pengetahuan profesional yang dimiliki guru untuk mencapai tujuan kurikulum. Sedangkan menurut UU No. 21 tahun 2003 tentang SISDIKNAS, pembelajaran adalah proses interaksi peserta didik dengan pendidik dan sumber ajar pada suatu lingkungan belajar.

Menurut (Jauhar, 2019) Metode pembelajaran adalah seperangkat metode untuk mencapai tujuan pembelajaran tertentu, dan merupakan rencana komprehensif untuk mencapai tujuan pembelajaran dan membutuhkan sejumlah langkah, prosedur, metode, dan kegiatan di dalam kelas. Berikut adalah metode pembelajaran dalam bahasa asing, adalah:

\section{Grammar-Translation Method}

Metode ini merupakan metode tertua, tidak didasarkan pada teori tertentu pada ide linguistik atau pedagogis tertentu dan juga tidak didasarkan pada teori tertentu, melainkan berakar pada pengajaran bahasa Latin dan Yunani yang berpusat pada pengajaran tata bahasa dan terjemahan.

Para ilmuwan telah mengklasifikasikan metode ini diantara metode sekolah kuno untuk mengajarkan bahasa asing yang masih lazim sampai sekarang di berbagai daerah di dunia.

\section{Direct Method}

Metode langsung - muncul sebagai respons terhadap jalur tata bahasa dan terjemahan, yang tidak didasarkan pada pandangan ilmiah 
bahasa apapun yang tidak memiliki dasar sistematis dalam pertanyaannya. Metode ini kadang-kadang disebut cara alami, karena akar sejarahnya merujuk pada prinsip-prinsip alami pengajaran bahasa.

Oleh karena itu, pengajaran bahasa asing tidak harus melalui terjemahan, karena pengajaran makna dari kata-katanya dapat dilakukan melaui akting, gerakan, gambar, dan penggunaan spontan di dalam kelas.

\section{Audio-lingual Method}

Metode ini muncul sebagai tanggapan terhadap tata bahasa, terjemahan, dan metode langsung bersama di satu sisi, dan sebagai tanggapan terhadap minat yang semakin besar dalam mempelajari bahasa asing di Amerika pada tahun 50-60an untuk mengikuti apa yang terjadi di dunia perkembangan.

Dilakukan studi linguistik yang mengarah pada munculnya pendekatan baru terhadap bahasa, termasuk bahwa bahasa adalah ucapan bukan tulisan, dan itu adalah seperangkat kebiasaan yan dipraktekkan oleh rakyatnya. Prinsip ini menghasilkan munculnya metode baru di bidang pengajaran bahasa asing, yang disebut metode audio lisan.

Bahasa Arab adalah salah satu bahasa kuno yang disebut kelompok bahasa Semit relatif terhadap Samit bin Noah. Diantara kelompok-kelompok bahasa Semit adalah bahasa Kanaan, Nabatean, Babel, dan Abyssinian. Bahasa Semit hanya memiliki 19 monumen yang diukir di bebatuan.

Bahasa Arab merupakan bidang studi yang dikenal masyarakat terutama pada aspek lembaga Islam dan di dalamnya mencantumkan bidang studi bahasa Arab sebagai salah satu bidang studi yang dianggap penting. Dengan demikin bahasa Arab statusnya sama dengan bahasa asing lainnya yang menjadi bidang studi di setiap sekolah.

Menurut (Jauhar, 2019) Pembelajaran bahasa Arab dan tujuan pembelajaran bahasa Arab bagi penutur asing, dibagi menjadi tiga, yaitu: 
a. Melatih siswa untuk mempraktekan bahasa Arab dengan cara yang mirip dengan penutur asli, mengingat empat keterampilan berbahasa berarti mengajarkan kepada penutur asing untuk hal-hal berikut:

- Untuk mengembangkan kemampuan siswa untuk memahami bahasa Arab ketika ia mendengarnya.

- Untuk mengembangkan keterampilan mengucapkan bahasa dengan baik dan benar.

- Untuk mengembangkan kemampuan siswa untuk membaca tulisan Arab dengan akurasi dan pemahaman.

- Untuk mengembangkan kemampuan siswa menulis dalam bahasa Arab secara akurat dan lancar.

b. Siswa mengetahui karakteristik bahasa Arab dan keistimewaannya dalam hal suara (ashwat), kosa kata, struktur, dan konsep.

c. Siswa mengetahui budaya Arab, lingkungan, dan karakteristik orang Arab.

Dalam mempelajari bahasa Arab, mempunyai empat keterampilan berbahasa, antara lain sebagai berikut: keterampilan menyimak (maharah istima'), keterampilan berbicara (maharah kalam), keterampilan membaca (maharah qiro'ah), dan keterampilan menulis (maharah kitabah). Namun pada kenyataannya, sebagian besar siswa merasa kesulitan untuk belajar bahasa Arab. Minat siswa dalam belajar bahasa Arab sangat rendah. Banyak faktor yang mempengaruhi rendahnya minat belajar bahasa Arab, termasuk metode dan model pengajaran yang kurang efektif dan kurang baru.

Pendidikan jarak jauh adalah metode pengajaran dimana kegiatan pendidikan telah dilakukan terpisah dari kegiatan sains karena siswa yang terpisah jarak antara tempat tinggal dan situs lembaga, dan hal tersebut merupakan karakteristik khas untuk pembelajaran jarak jauh. Pembelajaran ini dapat mengatasi beberapa masalah, termasuk mendefinisikan guru yang terampil, jarak antara lembaga pendidikan dan siswa jauh satu sama lain, dan kurangnya guru yang berkualitas. (Al-Hayari, 2017) 
Keistimewaan pembelajaran jarak jauh: 1. Kenyamanan: sangat cocok untuk dipakai semua individu; 2. Fleksibilitas: menyediakan area dan pilihan bai pelajar sesuai dengan keinginannya untuk berpartisipasi; 3 . Dampak: ini ditandai dengan meninggalkan lebih banyak pengaruh dan efektivitas daripada sistem pendidikan tradisional; 4. Berkontribusi dalam meningkatkan budaya, ilmiah, dan sosial dari anggota masyarakat; 5. Mengurangi beban administrasi guru.

Pendidikan jarak jauh (PJJ) ini sudah terlebih dahulu diterapkan di negara-negara maju, dari data yang diperoleh oleh UNESCO (1989) PJJ sudah diterapkan di Amerika Serikat pada tahun 1892, Australia dan Selandia Baru sejak awal tahun 1922, sedangkan Inggris pada tahun 1966 dan dianggap paling berhasil menerapkan pembelajaran jarak jauh. Dengan diterapkannya PJJ di negara maju, maka dapat disimpulkan bahwa pendidikan jarak jauh sudah diakui oleh berbagai negara dan bisa diterapkan untuk mengatasi berbagai permasalahan pendidikan. Keterbatasan ruang dan waktu yang dimiliki oleh siswa dapat diatasi dengan cara memanfaatkan berbagai sumber belajar melalui teknologi komunikasi, informasi, dan media lain. Salah satu pembelajaran dalam pendidikan jarak jauh dilakukan dengan e-learning dimana pembelajarannya mengunakan rangkaian eletronik untuk menyampaikan isi pembelajaran, interaksi, atau bimbingan (Indriani dkk, 2018).

Di era teknologi yang semakin maju, internet terus tumbuh secara global, dan di Indonesia sendiri internet telah tumbuh secara merata. Perkembangan internet didukung oleh sejumlah smartphone dari berbagai jenis dan merek untuk memudahkan pengguna untuk mengakses internet. Perkembangan teknologi informasi dan komunikasi telah membawa perubahan yang sangat besar bagi kemajuan dunia pendidikan. Seiring dengan perkembangan tersebut metode pembelajaran juga banyak mengalami perkembangan, baik metode pembelajaran secara personal, media pembelajaran, ataupun proses pembelajaran. 
Penggunaan media daring sebagai sarana pendidikan ini mulai menjadi alternatif dalam dunia pendidikan. Dalam menyampaikan materimateri pendidikan seorang pendidik bisa saja memiliki akun sosial media, seperti: facebook, twitter, instagram, LINE, Whatssapp, atau media daring lainnya, seperti: youtube, google accounts, linkeidn, dan lain-lain. Selain sebagai sarana komunikasi, media daring pun bisa menjadi sarana pembelajaran. Apalagi di saat ini, saat terjadinya pandemi covid-19 yang menuntut kita untuk tetap dalam rumah. Maka dilakukanlah pembelajaran via daring. Menurut Usman dalam jurnal Al-Tsiqoh (2016) bahwa media daring sangat efektif untuk berdakwah, di dalam media daring dapat digunakan untuk mencari literatur pengetahuan agama.

Menurut Kaplan \& Haelein (hal.61) media sosial adalah seperangkat aplikasi web yang dibangun berdasarkan ideologi dan teknologi web 412.0 yang memungkinkan pembuatan dan pertukaran konten yang disediakan pengguna.

Berdasarkan web Whatssapp yang menceritakan tentang sejarah whatssapp bahwasanya whatssapp bersaing dengan sejumlah layanan instant massage, seperti KakaoTalk, Line, dan WeChat. Karier Whatssapp dimulai sebagai alternatif SMS. Namun sekarang media daring Whatssapp mencakup pengiriman dan penerimaan berbagai jenis media, termasuk pesan teks, foto, video, dokumen, lokasi geografis, dan pesan suara.

Whatssapp didirikan oleh Bancom dan BrainActin yang bekerjasama di Yahoo karena jumlah total tahun layanan mencapai 20 tahun. Lebih dari satu milyar orang menggunakan whatssapp dari 180 negara untuk tetap berhubungan dengan teman dan anggota keluarga dimana saja dan kapan saja.

Meskipun dengan adanya keunggulan-keunggulan pada penggunaan media daring pada pembelajaran jarak jauh tetap saja peserta didik memerlukan umpan balik dari pengajar begitu pula sebaliknya. Untuk itu munculah konsep pembelajaran Project Based Learning (PjBL). (Wena, 
2014, p. 14) menyatakan bahwa model Project Based Learning merupakan model pembelajaran di kelas dengan melibatkan kerja proyek. Kerja proyek merupakan suatu bentuk kerja yang memuat tugas-tugas kompleks berdasarkan kepada pertanyaan dan permasalahan yang sangat menantang dan menuntun peserta didik untuk merancang, memecahkan masalah, membuat keputusan, melakukan kegiatan invetigasi, serta memberikan kesempatan peserta didik untuk bekerja secara mandiri.

Dari obseravasi, dapat diketahui bahwa MTs AI-Wathoniyah AlHamidiyah memiliki kesiapan dalam melaksanakan Project Based Learning. Kesiapan tersebut bukanlah dari faktor guru dan siswa, namun dari pihak pengelola sekolah serta fasilitas kedua belah pihak pun sudah cukup memadai untuk dilaksanakannya Project Based Learning.

Oleh karena itu, peneliti tertarik untuk membahas perihal Project Based Learning di MTs Al-Wathoniyah Al-Hamidiyah khususnya kelas 7B dengan mata pelajaran Bahasa Arab.

\section{LANDASAN TEORETIS DAN METODE}

Metode yang digunakan dalam penelitian ini adalah menggunakan pendekatan kualitatif. Penelitian kualitatif dinamakan sebagai metode baru, karena popularitasnua belum lama, dinamakan post-positivistik karena berlandaskan pada filsafat post-positivistik. Pada penelitian ini data yang dikumpulkan bukan berupa angka, melainkan naskah, wawancara, catatan lapangan, rekaman, dan dokumen pribadi (Sugiyono, 2013, p. 7).

Dalam pelaksanaan penelitian ini hanya terdapat satu variabel atau variabel tunggal. Artinya dalam penelitian ini peneliti hanya melakukan penelitian terhadap satu gejala yang dimiliki berbagai aspek atau kondisi di dalamnya yang berfungsi mendominasi dalam kondisi atau masalah tanpa dihubungkan dengan lainnya. Varian yang ada dalam penelitian ini yaitu implementasi project based learning. 
Metode penelitian yang akan digunakan adalah metode deskriptif jenis case study (studi kasus). Studi kasus adalah sebuah model yang memfokuskan eksplorasi atas satu kasus ataupun pada sebagian kasus secara terperinci dengan menggunakan data secara mendalam. Beragam sumber informasi yang kaya akan konteks dilakukan untuk penggalian data (Cresswel, 2015).

Penelitian metode deskriptif jenis studi kasus dalam penelitian ini didasari oleh maksud yang ingin megkaji secara mendalam tentang implementasi project based learning dalam program pendidikan jarak jauh di MTs AI-Wathoniyah Al-Hamidiyah.

Penelitian ini dilaksanakan di MTs AI-Wathoniyah Al-Hamidiyah yang berlokasi di JI. I Gusti Ngurah Rai No.62 RT 15 Rw 17, Klender, Kec. Duren Sawit, Jakarta Timur, DKI Jakarta. Lokasi ini dipilih karena MTs AIWathoniyah Al-Hamidiyah memiliki kesiapan baik dari guru, peserta didik, serta fasilitas yang mumpuni sehingga project based learning dapat dilaksanakan.

Dalam penelitian kualitatif penumpulan data dilakukan pada kondisi alamiah (natural setting) yang terjadi di lapangan. Sumber data dan teknik pengumpulan lebih banyak pada wawancara mendalam (in depth interview), observasi, dam studi dokumentasi.

Analisis data dalam penelitian ini dilakukan dengan berbagai tahapan, yaitu: reduksi data, display data, dan penarikan kesimpulan. Sedangkan untuk pengujian keabsahan data dilakukan dengan member check dan tringulasi data.

Tringulasi data dalam penelitian ini dilakukan dengan berbagai tahapan yaitu: 1. Membandingkan data hasil wawancara narasumber dengan narasumber lain, 2. Membandinkan hasil wawancara dengan hasil observasi dan studi dokumentasi yang telah dilakukan. Selanjutnya uji kebasahan data dilakukan dengan member check yang telah dilakukan setelah satu periode 
pengumpulan data selese, atau setelah mendapatkan suatu temuan, atau kesimpulan, peneliti datang kepada pemberi data untuk menyepakati data hasil penelitian. Setelah data disepakati bersama, maka para pemberi data diminta untuk menandatangani supaya lebih otentik (Indriani dkk, 2018).

\section{HASIL dan PEMBAHASAN}

Berikut ini peneliti deskripsikan hasil dan pembahasan berdasarkan masing-masing fokus permasalahan yang ingin peneliti kaji secara mendalam terkait pengaruh penggunaan whatssapp dan metode pembelajaran project based learning terhadap pembelajaran bahasa Arab di Mts Al-Wathoniyah AlHamidiyah.

\section{Perencanaan Pembelajaran Project Based Learning}

Menurut RISTEKDIKTI tahun 2016, Pendidikan Jarak Jauh merupakan proses pendidikan yang terorganisasi yang menjembatani keterpisahan antara siswa dengan guru dan dimediasi oleh pemanfaatan teknologi. Sedangkan dalam UU nomor 12 tahun 2012 pasal 31 tentang pendidikan tingi menyebutkan bahwa pendidikan jarak ajuh merupakan proses belajar mengajar yang dilakukan secara jarak jauh melalui penggunaan berbagai media komunikasi, sehingga dapat diketahui pendidikan jarak jauh adalah proses kegiatan belajar mengajar yang dapat dilaksanakan dimana saja meskipun tidak dalam ruang lingkup sekolah, dengan memanfaatkan terknologi informasi dan komunikasi (Khaerunnisa, 2019)

Program pendidikan jarak jauh ini bertujuan untuk menaati perintah dari pemerintah semenjak munculnya pandemi covid-19 di seluruh dunia. Pandemi covid-19 memaksan Kementrian Pendidikan dan Kebudayaan menerapkan sistem pembelajaran jarak jauh dengan jaringan teknologi internet di sekolah (Kamil, 2020).

Pendidikan jarak jauh di MTs AI-Wathoniyah Al-Hamidiyah Jakarta menerapkan pembelajaran secara project based learning yang berarti 
pembelajaran yang berpusat pada siswa dan memberikan pengalaman belajar yang bermakna bagi peserta didik. Pelaksanaan pendidikan jarak jauh di MTs Al-Wathoniyah Al-Hamidiyah Jakarta terbilang baru, karena baru berjalan pada tanggal 16 Maret 2020, untuk itu perangkat pembelajaran digitalnya pun masih dalam tahap persiapan. Proses pelaksanaannya dilakukan tidak semata-mata menggunakan aplikasi daring whatssapp akan tetapi menggunakan project based learning.

Aplikasi daring whatssapp dapat diunduh di google playstore atau di apple store yang tersedia di smartphone, pengguna hanya menggunakan koneksi internet saja. Peran guru juga menjadikan perkembangan media sosial sebagai sarana penyampaian materi yang bersifat edukatif sangatlah penting.

Pemilihan mata pelajaran bahasa Arab sebagai uji coba dalam program pendidikan jarak jauh ini mengingat bahwa pelajaran bahasa Arab di MTs Al-Wathoniyah Al-Hamidiyah Jakarta merupakan pelajaran kurikulum dan juga guru bidang studi dirasa memiliki kompetensi baik dari segi kreatifitas yang dimiliki guru serta kemampuan untuk memanfaatkan teknologi yang ada

Pelaksanaan guru bidang studi bahasa Arab di MTs Al-Wathoniyah Al-Hamidiyah Jakarta dalam perencanaan pelaksanaan project based learning dengan pendapat Rais (dalam Lestari: 2015) langkah-langkah model pembelajaran project based learning adalah sebagai berikut:

1. Membuka pelajaran dengan suatu pertanyaan menantang. Pembelajaran dimulai dengan driving question yang dapat memberi penugasan pada siswa untuk melakukan suatu aktivitas. Topik yang diambil hendaknya sesuai dengan realita dunia nyata dan dimulai dengan sebuah investigasi yang mendalam.

2. Merencanakan proyek. Perencanaan dilakukan secara kolaboratif antara pendidik dengan peserta didik. Dengan demikian peserta didik diharapkan akan merasa memiliki atas proyek tersebut. Perencanaan berisi tentang aturan main, pemilihan aktivitas yang dapat mendukung dalam menjawab pertanyaan esensial dengan mengintegrasikan 
berbagai subyek yang mendukung, serta menginformasikan alat dan bahan yang dimanfaatkan untuk menyelesaikan proyek.

3. Menyesuaikan jadwal aktivitas. Pendidik dan peserta didik secara kolaboratif menyusun jadwal aktivitas dalam menyelesaikan proyek. Waktu penyelesaian proyek harus jelas, dan peserta didik diberi arahan untuk mengelola waktu yang ada.

4. Mengawasi jalannya proyek. Pendidik bertanggung jawab untuk melakukan monitor terhadap aktivitas peserta didik selama menyelesaikan proyek. Monitoring dilakukan dengan cara memfasilitasi siswa pada setiap proses.

5. Penilaian terhadap produk yang dihasilkan. Penelitian dilakukan untuk membantu pendidik dan mengukur ketercapaian standar, berperan dalam mengevaluasi kemajuan masing-masing siswa, memberi umpan balik tentang tingkat pemahaman yang sudah dicapai oleh siswa, serta membantu dalam menyusun strategi pembelajaran berikutnya. Penilaian produk dilakukan saat masingmasing kelompok mempresentasikan produknya di depan kelompok lain secara bergantian.

6. Evaluasi. Pada akhir proses pembelajaran, guru dan siswa melakukan refleksi dilakukan baik secara individu maupun kelompok (Lestari, 2015).

Berdasarkan tulisan di atas, mengenai project based learning. Karakteristik model project based learning yaitu: peserta didik dihadapkan pada permasalahan konkret, mencari solusi, dan mengerjakan proyek dalam tim untuk mengatasi masalah tersebut. Namun peserta didik tidak hanya memahami konten, tetapi juga menumbuhkan keterampilan pada peserta didik bagaimana berperan di masyarakat. Keterampilan yang ditumbuhkan dalam project based learning diantaranya keterampilan komunikasi dan presentasi, manajemen organisasi dan waktu, keterampilan penelitian dan penyelidikan, keterampilan penilaian diri dan refleksi, partisipasi kelompok dan kepemimpinan, dan pemikiran kritis.

\section{Pelaksanaan Pembelajaran Project Based Learning}

Berdasarkan hasil penelitian yang dilakukan peneliti, dapat diketahui bahwa pembelajaran jarak jauh menggunakan project based learning di MTs Al-Wathoniyah Al-Hamidiyah Jakarta baru berjalan dua bulan terhitung dari bulan Maret 2020 sampai dengan keputusan pemerintah memperbolehkan masuk sekolah kembali. 
Pelaksanaan pembelajaran bahasa Arab kelas 7B MTs AlWathoniyah Al-Hamidiyah Jakarta dilaksanakan tiap hari Selasa pukul 09.3010.50 secara daring. Pembelajaran akan menggunakan whatssapp group untuk memulai pelajaran. Batas akhir pengumpulan tugas pukul 14.00, diimbau peserta didik untuk mengumpulkan tugas sebelum waktu yang ditentukan.

Media pembelajaran yang digunakan dalam pembelajaran project based learning adalah laptop atau smartphone milik guru, bahan ajar soft file, dan jaringan internet. Sedangkan media pembelajaran yang dibutuhkan siswa adalah laptop atau smartphone, kertas/buku, pulpen, dan jaringan internet.

Pada kegiatan awal pembelajaran, guru akan memberi pesan di whatssapp group. Diawali dengan mengucapkan salam pembuka, melakukan absensi kehadiran peserta didik, dan menanyakan kesiapan untuk mengikuti pelajaran. Setelah dikira semua peserta didik siap untuk mengikuti materi pembelajaran, maka guru pun siap untuk memberikan bahan ajar soft file. Jumlah peserta didik kelas 7B yang akan mengikuti pembelajaran berjumlah 30 siswa. Sumber daya manusia yang terlibat dalam pelaksanaan pembelajaran project based learning dalam program PJJ di MTs AIWathoniyah Al-Hamidiyah meliputi kepala sekolah, pendidik, peserta didik, dan juga kerjasama dengan orang tua. Untuk menyampaikan materi pembelajaran, guru dapat menggunakan media aplikasi whatssapp group, quiziz, ataupun youtube. Pada pendekatan project based learning, guru berperan sebagai fasilitator bagi siswa untuk memperoleh jawaban dari pertanyaan penuntun, sedangkan pada kelas "konvensional" pengajar dianggap sebagai penguasa yang paling menguasai materi dan karenanya semua informasi diberikan secara langsung pada peserta didik.

Pada kegiatan selanjutnya, guru akan memberikan materi ajar yang berkaitan dengan materi sebelumnya. Contoh kali ini, guru akan memberikan materi kosakata tentang keluarga. Setelah semua materi tersampaikan 
kepada peserta didik, maka peserta didik tersebut mencatat materi yang telah disampaikan. Setelah itu guru memberikan contoh peragaan tentang pengenalan anggota keluarga di youtube. Kemudian guru tersebut memberikan tugas kepada peserta didik untuk memperkenalkan anggota keluarga dengan menggunakan bahasa Arab. Materi yang disampaikan secara tidak langsung telah melatih empat kemahiran berbahasa, yaitu: kemahiran menyimak, kemahiran berbicara, kemahiran menulis, dan kemahiran membaca.

Kegiatan yang dilakukan oleh guru dirasa telah dapat memanfaatkan teknologi dengan baik, sehingga virtual classroom yang dilakukan tidak monoton dan menarik perhatian siswa. Selama pembelajaran guru akan terus mendampingi kegiatan belajar mengajar walaupun dilakukan secara daring.

Kegiatan penutup yang dilakukan oleh guru adalah mengabsen kembali peserta didik yang telah mengumpulkan tugas. Setelah itu guru mengevaluasi peserta didik selama pembelajaran tadi berlangsung.

\section{Evaluasi Pembelajaran Project Based Learning}

Sistem evaluasi dalam pembelajaran project based learning program pendidikan jarak jauh program pendidikan jarak jauh dilakukan melalui: 1 . Tes Mandiri, yaitu penilaian pencapaian dilakukan secara mandiri; 2. Tes guru, yaitu pencapaian penilaian yang dilakukan oleh guru pada peserta didik setelah menyelesaikan tugas; 3. Evaluasi Akhir Peserta Didik, yaitu penilaian yang dilakukan secara berkala kepada peserta didik, disebut juga dengan Ujian Tengah Semester dan Ujian Akhir Semester.

Teknik yang digunakan dalam evaluasi project based learning adalah teknik tes dan non tes. Teknik non tes yang digunakan pada penelitian adalah menggunakan penelitian portfolio, proyek, dan presentasi, sedangkan teknik tes menggunakan tes uraian. Dengan teknik nontes maka penilaian hasil belajar siswa dilakukan tanpa menguji siswa, melainkan dengan pengamatan. Pengamatan yang dilakukan pada proses penelitian adalah 
pengamatan untuk nilai portofolio, proyek, dan presentasi. Sedangkan dengan teknik tes yang digunakan adalah tes tulis yang dilakukan untuk mengungkap daya ingt dan pemahaman siswa terhadap materi pelajaran (Dede Irawan Saputra, 2014).

Dengan teknik tes dan non tes, siswa diharapkan dapat mengembangkan softskill dalam pembelajaran. Siswa dituntut untuk aktif bekomunikasi, berkolaborasi, dan bertanggung jawab serta berfikir kritis, kreatif, dan rasional dalam menyelesaikan tugas.

Hasil evaluasi pembelajaran merupakan akumulasi keseluruhan nilai dari menyelesaikan tugas, evaluasi tengah semester, evaluasi akhir semester, dan akumulasi nilai akhlak di whatssapp group. Dalam pembelajaran daring semua informasi diberikan secara transparan antara guru, siswa, dan orang tua siswa melalui whatssapp group.

4. Faktor Penghambat dan Faktor Pendukung Pembelajaran Project Based Learning

Menurut (Wena, 2014, p. 147)model pembelajaran project based learning mempunyai beberapa kekurangan dan kelabihan, sebagai berikut:

1. Kelebihan model pembelajaran project based learning: meningkatkan motivasi, meningkatkan kemampuan memecahkan masalah, meningkatkan kolaborasi, meningkatkan keterampilan mengelola sumber, dan increased resource - management skill.

2. Kelemahan model pembelajarn project based learning: menemukan banyak waktu yang harus diselesaikan untuk menyelesaikan masalah, memerlukan biaya yang cukup banyak, dan banyak peralatan yang harus disediakan.

Menurut hasil wawancara dengan narasumber (guru bidang studi bahasa Arab di MTs Al-Wathoniyah Al-Hamidiyah) terdapat beberapa kekurangan dan kelebihan dari pembelajaran jarak jauh, diantaranya adalah: 
1. Kekurangan: jaringan yang tidak stabil, penyampaian teknik praktik yang harus berulang-ulang dari siswa karena kurang memahami tugas yang diberikan melalui whatssapp group.

2. Kelebihan: materi tersampaikan lebih baik, dan pembelajaran terlaksana lebih kondusif.

\section{SIMPULAN}

Berdasarkan hasil penelitian dan analisis data yang dilakukan oleh peneliti, maka dapat disimpulkan secara umum bahwa dalam rangka pelaksanaan pendidikan jarak jauh penggunaan aplikasi daring whatssapp sangat mampu untuk menggabungkan kerja sama antara pendidik, peserta didik, dan wali murid. Penggunaan metode pembelajaran project based learning mampu mengatasi keterbatasan dan kekurangan selama pembelajaran dengan cara daring.

Beberapa kesimpulan dari temuan hasil penelitian bahwa implementasi pembelajaran project based learning dalam program pendidikan jarak jauh yang dilaksanakan MTs AI-Wathoniyah Al-Hamidiyah terdapat kegiatan perencanaan, pelaksanaan, evaluasi, dan faktor kelebihan dan kekurangan.

\section{DAFTAR PUSTAKA}

Al-Hayari. (2017, 02 05). pembelajaran jarak jauh. Dipetik 05 29, 2020, dari mawdoo.com: https://mawdoo3.com

Al-Jaburi, I. J. (2013). Al-Manhaj wa Tharaiq Tadris Al-Lughah Al-Arabiyah. Yordania: Dar El-Ridwan.

Cresswel, J. (2015). Penelitian Kualitatif dan Desain Riset. Yogyakarta: Pustaka Pelajar.

Dede Irawan Saputra, A. G. (2014). PENGEMBANGAN MODEL EVALUASI PEMBELAJARAN PROJECT BASED LEARNING BERBASIS LOGIKA FUZZY. INVOTEC, 13-34.

Gulo, W. (2002). Strategi Belajar Mengajar. Jakarta: Grasindo. 
Indriani dkk, T. T. (2018). Implementasi Blended Learning Dalam Pendidikan Jarak Jauh Pada Jenjang Pendidikan Menengah Kejuruan. Edutechnologia.

Jauhar, N. (2019). Thariq Tadris Al-Lughah Al-Arabiyah Lil Natiqin BiGhairiha. Surabaya: UIN Sunan Ampel.

Kamil, I. (2020, September 03). Kilas Balik Pembelajaran Jarak Jauh akibat Pandemi Covid-19. Retrieved from https://nasional.kompas.com

Khaerunnisa, F. K. (2019). Evaluasi Penerapan Blended Learning Pada Pembelajaran Bahasa Arab Di SMPIT Ibadurrahman Studi Kasus Di Kelas VII Akhwat. Alsuniyat, 95-108.

Lestari, T. (2015). Peningkatan Hasil Belajar Kompetensi Dasar Menyajikan Contoh-Contoh llustrasi Dengan Model Pembelajaran Project Based Learning dan Metode Demonstrasi Bagi Siswa Kelas XI Multimedia SMK Muhamadiyah Wonosari. Yogyakarta: Universitas Negeri Yogya.

Sugiyono, P. (2013). Metode Penelitian Kuantitatif Kualitatif dan R\&D. Bandung: Alfabeta.

Wena, M. (2014). Strategi Pembelajaran Inovatif Kontemporer: Suatu Tinjauan Konseptual Operasional. Jakarta: Bumi Aksara. 